\title{
A Review of Three Phase AC-DC Power Factor Correction Converters for Electric Vehicle Fast Charging
}

\author{
Merve Mollahasanoglu ${ }^{1 *}$, Halil Ibrahim Okumus ${ }^{2}$ \\ ${ }^{1 *}$ Karadeniz Technical University, Faculty of Engineering, Department of Electrical and Electronics Engineering, Trabzon, Turkey, (ORCID: 0000-0002-6133-2717), \\ merve.aydin@ktu.edu.tr \\ ${ }^{2}$ Karadeniz Technical University, Faculty of Engineering, Department of Electrical and Electronics Engineering, Trabzon, Turkey, (ORCID: 0000-0002-4303-5057), \\ okumus@ktu.edu.tr
}

(International Conference on Design, Research and Development (RDCONF) 2021 - 15-18 December 2021)

(DOI: $10.31590 /$ ejosat.1041081)

ATIF/REFERENCE: Mollahasanoglu, M. \& Okumuş, H.İ. (2021). A Review of Three Phase AC-DC Power Factor Correction Converters for Electric Vehicle Fast Charging. European Journal of Science and Technology, (32), 663-669.

\begin{abstract}
Electric vehicle charging station for fast DC charging performs AC-DC conversion at off-board. In recent years, three-phase AC-DC power factor correction (PFC) converters are dealt with fast charger. These converters are developed using unidirectional and bidirectional power flow structure. In this study, three-phase AC-DC PFC converter topologies, providing bidirectional power flow, are evaluated in terms of performance. The aim is to present the latest technology of bidirectional multilevel AC-DC PFC converters for EV fast charging. This paper provides a comprehensive and practical review for researchers interested in fast charging infrastructure for electric vehicles.
\end{abstract}

\section{Elektrikli Araçların Hızlı Şarjı için Üç Fazlı AA-DA Güç Faktörü Düzeltme Dönüştürücülerinin İncelenmesi}

Öz

Hızlı DA şarj için elektrikli araç şarj istasyonu, araç dışında AA-DA dönüşümü gerçekleştirir. Son yıllarda, üç fazlı AA-DA güç faktörü düzelten (GFD) dönüştürücüler hızlı şarj cihazı ile birlikte ele alınmaktadır. Bu dönüştürücüler, tek yönlü ve çift yönlü güç akışı yapısı kullanılarak geliştirilmiştir. Bu çalışmada, çift yönlü güç akışı sağlayan üç fazlı AA-DA GFD dönüştürücü topolojileri performans açısından değerlendirilmiştir. Amaç, elektrikli araç hızlı şarjı için en yeni üç fazlı çift yönlü çok seviyeli AA-DA GFD dönüştürücü teknolojisini sunmaktır. Bu makale, elektrikli araçlar için hızlı şarj altyapısıyla ilgilenen araştırmacılar için kapsamlı ve pratik bir inceleme sunmaktadır.

Anahtar Kelimeler: İyileştirilmiş güç kalitesi, AA-DA dönüştürücüler, Güç faktörü düzeltme, Üç fazlı AA-DA dönüştürücüler, Hızlı şarj altyapısı. 


\section{Introduction}

Researches based on the use of clean and efficient fuels in the automotive sector continue. Therefore, the interest in electric vehicles is increasing. However, electric vehicle (EV) users are concerned about the charging times of the vehicles and the range they can travel. This situation leads researchers to improve the charging infrastructure in fast charging stations.

Electrical energy is not in a form that can be directly applied to the EV battery. EV chargers transmit energy as the form of high voltage AC or DC current. AC chargers provide AC power form to the $\mathrm{EV}$, then $\mathrm{AC}$ power form is converted to DC using on-board charging unit. On-board chargers are slow because they operate at lower currents (Metwly et al., 2020; Sam et al., 2021; Yuan et al., 2021). DC (off-board) chargers transform AC current externally and provide high power directly to the EV battery (Chlebis et al., 2014; Monteiro et al., 2020). Therefore, it is quite fast. Fast DC charging stations established for commercial purposes provide desired high energy with three-phase power supply (Monteiro et al., 2018; Yildirim et al., 2020). Figure 1 shows general fast charging infrastructure for EV.

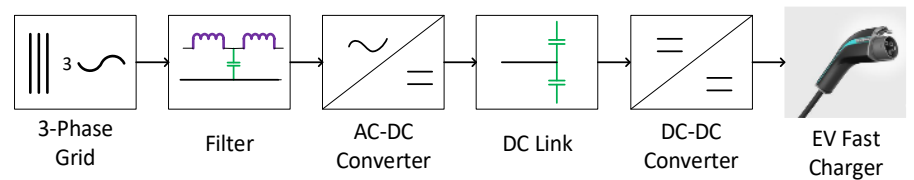

Figure 1. General fast charging infrastructure for EV

The fast charging infrastructure has a power system flow and power electronics converters affect the occurred harmonics and reactive power in this system. AC-DC converters are used with passive, active and hybrid filters due to power quality problems as in (Balasubramanian et al., 2016; Justus Rabi et al., 2015; Kushwaha et al., 2020a; Sah et al., 2021). However, filters are quite costly, bulky and have losses. These reduce the AC-DC converters performance (Singh et al., 2011). The converters selected for EV charging are important in terms of power quality, THD, reduced-rippled DC output and control approaches (Praneeth et al., 2018).

AC-DC converters supplied from three-phase AC mains are developed by using diodes, thyristors and controlled switches to provide controlled-uncontrolled and unidirectional bi-directional DC power in high power applications. Power quality problems and fluctuating DC output at the load end occur in the converter due to the injected current harmonics. Therefore, designers take into account standards guidelines. When we look at the literature, we can see that three-phase bidirectional multilevel AC-DC PFC converters are used for fast charging because of their efficiency as in (Khaligh et al., 2012; Nayak, 2019; Sandoval et al., 2015; Sharma et al., 2020; Singh et al., 2004; Tan et al., 2016; Verma et al., 2019; Yilmaz et al., 2013; Zhang et al., 2012). Therefore, this paper provides information about these converters topologies in detail.

Three-phase AC-DC converters are widely employed in adjustable-speeds drive (ASDs), uninterruptible power supplies (UPSs), high voltage DC transmission (HVDC), renewable energy systems, battery management systems and EV fast charging, etc. (Akter et al., 2015; Alves et al., 2018; Chen et al., 2016; Garg et al., 2015; J. H. Lee et al., 2011; J. Y. Lee et al., 2020; Soeiro et al., 2012; Wang et al., 2019). In the literature, this converters are classified as switch mode rectifiers (SMRs), power factor correction converters (PFCs), pulse width modulation (PWM) rectifiers (Bhat et al., 2008). These topologies are presented in detail in Figure 2.

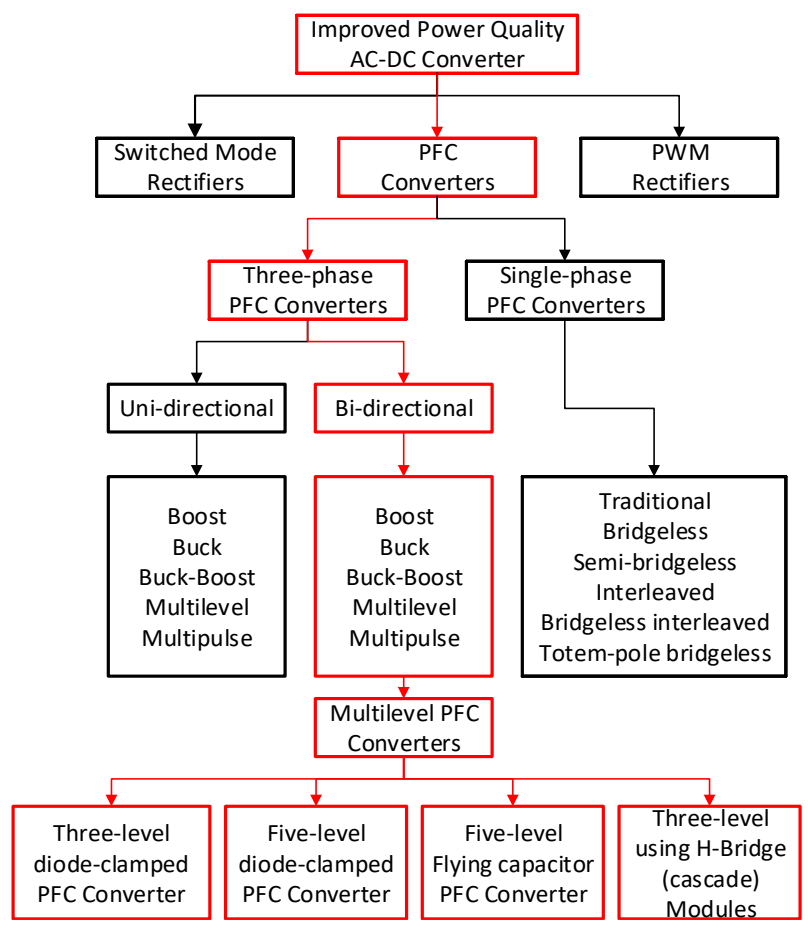

Figure 2. Classification of AC-DC converters with improved power quality

Today developed AC-DC converters with improved power quality are controlled by switching elements such as MOSFETs, IGBTs, GTOs, etc. (Elrajoubi et al., 2019). On-board and offboard charging topologies are included in the AC-DC PFC section as in (K. T. Chau, 2016; Kushwaha et al., 2020b). Firstly, singlephase and three-phase AC-DC PFC topologies for EVs charging were examined. Since the research is for high power applications, three-phase topologies are discussed.

In this study, the aim is to compare three-phase bi-directional PFC converters used in EV fast charging station. Then, multilevel PFC converter topologies ones were evaluated. With detailed information, researchers can obtain information fast about EV offboard charging.

\section{Evaluation of Three-Phase Bidirectional PFC Converters}

Three-phase unidirectional AC-DC PFCs are supported by choppers, SEPIC, Cuk, Zeta, full-bridge-half-bridge, fly-back or multi-level converters following a three-phase full diode bridge to provide high power factor.

Three-phase bidirectional AC-DC PFCs consist of basic converters such as voltage source inverter topology or current source inverter topology (Bhat et al., 2008). Three-phase unidirectional AC-DC PFCs show a distortion greater than 5\% in terms of phase current harmonic as in (Channegowda et al., 2015). This is not suitable for the standards given in IEEE 1030-1987. Three-phase bidirectional buck, boost, buck-boost, multi-pulse and multilevel converter topologies give similar results. However, they are developed in terms of performance. For this reason, they are used for different target (Liu et al., 2020). Table 1 shows the required element number for multilevel PFC converters. 
Table 1. Comparison of power components required per-phase between multilevel PFC converters

\begin{tabular}{l|c|c|c|c}
\hline \multirow{2}{*}{\multicolumn{1}{c|}{ Table Head }} & \multicolumn{4}{c}{ Multilevel PFC Converters } \\
\cline { 2 - 5 } & $\begin{array}{c}\text { 3-Level } \\
\text { Diode-clamped }\end{array}$ & $\begin{array}{c}\text { 5-Level } \\
\text { Diode-clamped }\end{array}$ & $\begin{array}{c}\text { 5-Level } \\
\text { Flying-capacitor }\end{array}$ & $\begin{array}{c}\text { 3-Level } \\
\text { H-bridge cascaded }\end{array}$ \\
\hline Main power switches copy & 4 & 8 & 8 & 4 \\
\hline Clamping diodes & 2 & 12 & 0 & 0 \\
\hline DC-Bus capacitors & 2 & 4 & 4 & 1 \\
\hline Balancing capacitors & 0 & 0 & 6 & 0 \\
\hline
\end{tabular}

Table 2. Comparative features of three-phase AC-DC PFC converters (Monteiro et al., 2018)(Bhat et al., 2008; "IEEE 597-1983 IEEE Standard Practices and Requirements for General Purpose Thyristor DC Drives,” n.d.)

\begin{tabular}{l|c|c|c|c|c|c|c}
\hline $\begin{array}{c}\text { Three-phase } \\
\text { AC-DC } \\
\text { PFC } \\
\text { Converters }\end{array}$ & $\begin{array}{c}\text { Number of } \\
\text { Switches }\end{array}$ & $\begin{array}{c}\text { Switch } \\
\text { Stresses }\end{array}$ & Conducted EMI & $\begin{array}{c}\text { Power } \\
\text { levels }\end{array}$ & Efficiency & Performance & Cost \\
\hline $\begin{array}{l}\text { Boost } \\
\text { Converter }\end{array}$ & $\begin{array}{c}\text { Large in two-stage } \\
\text { conversion, small } \\
\text { in single-stage } \\
\text { conversion }\end{array}$ & $\begin{array}{c}\text { less with } \\
\text { soft-switching } \\
\text { techniques }\end{array}$ & $\begin{array}{c}\text { Can be } \\
\text { lesser with } \\
\text { soft-switching } \\
\text { techniques }\end{array}$ & $\begin{array}{c}\text { Low with } \\
\text { DCM } \\
\text { but can be } \\
\text { high } \\
\text { with CCM }\end{array}$ & $\begin{array}{c}\text { good, with sensor } \\
\text { less topologies and } \\
\text { applications with } \\
\text { reduced magnetic } \\
\text { size can be further } \\
\text { improved }\end{array}$ & Better & $\begin{array}{c}\text { pow for high } \\
\text { application } \\
\text { and single } \\
\text { stage } \\
\text { conversion }\end{array}$ \\
\hline $\begin{array}{l}\text { Buck } \\
\text { Converter }\end{array}$ & $\begin{array}{c}\text { Large in two-stage } \\
\text { conversion, small } \\
\text { in single-stage } \\
\text { conversion }\end{array}$ & $\begin{array}{c}\text { Low, can be } \\
\text { lesser with } \\
\text { soft-switching } \\
\text { techniques }\end{array}$ & Low & $\begin{array}{c}\text { Usually } \\
\text { low, } \\
\text { if the } \\
\text { converter is } \\
\text { based GTO, } \\
\text { then high }\end{array}$ & $\begin{array}{c}\text { Good, can be further } \\
\text { improved with Soft } \\
\text { switching and } \\
\text { transformer } \\
\text { isolation" }\end{array}$ & $\begin{array}{c}\text { Better, It also } \\
\text { has short- } \\
\text { circuit } \\
\text { protection, } \\
\text { good open- } \\
\text { loop control }\end{array}$ & $\begin{array}{c}\text { Low for in } \\
\text { low-power } \\
\text { application }\end{array}$ \\
\hline $\begin{array}{l}\text { Buck-Boost } \\
\text { Converter }\end{array}$ & Less & $\begin{array}{c}\text { Low, can be } \\
\text { lesser with } \\
\text { soft-switching } \\
\text { techniques }\end{array}$ & Low & Medium & Fairly good & $\begin{array}{c}\text { good with } \\
\text { DCM }\end{array}$ & Low \\
\hline $\begin{array}{l}\text { Multilevel } \\
\text { Converter }\end{array}$ & Large & Least & $\begin{array}{c}\text { Less with low dv/dt } \\
\text { and can be lesser } \\
\text { with soft switching } \\
\text { techniques }\end{array}$ & High & Very high & Excellent & $\begin{array}{c}\text { High due to number } \\
\text { of } \\
\text { switches }\end{array}$ \\
\hline
\end{tabular}

When we look at Table 2, we can see that three-phase bidirectional multilevel PFC topologies show the best PFC effect and reduce the voltage stress on the circuit elements, have lower THD and have good performance. Three-phase bi-directional multilevel PFC topologies provide high power quality, reduce THD and EMI, and have higher regulated DC output voltage (Habib et al., 2018; Turksoy et al., 2018). Using three-phase multi-level bidirectional converters is more appropriate for level 3 fast DC charger. These PFC converters are more efficient for grid input and safer compared to other topologies.

\section{Three-Phase Bidirectional Multilevel PFC Converters for Fast Charging}

High efficiency and low THD is important for high power and bi-directional power flow applications.
Three-phase bi-directional multilevel AC-DC PFC converters evaluated for fast charging are following. IGBT and MOSFET are ideal switch for low and medium power applications, but GTO is used for high power applications [42]. These converters are more successful than the applications with transformers according to (Yilmaz et al., 2013) and (Yaramasu et al., 2021).

Figure 3 shows three-level diode-clamped bi-directional PFC converter topology. Bidirectional boost converter and bidirectional neutral point clamped (NPC) topologies are compared in (Monteiro et al., 2018). NPC topology has the smallest ripple at the main current and shows smaller fluctuation in DC output. (Yilmaz et al., 2013) refers that this converter shows lower switching stress for level 3 fast charger applications. 


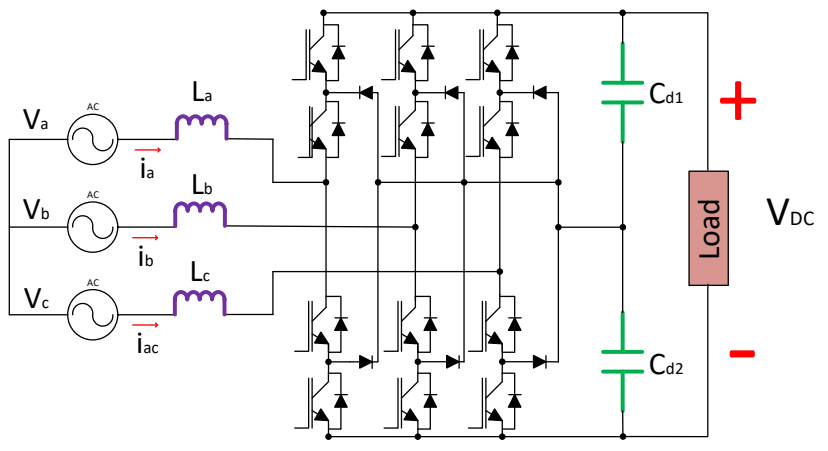

Figure 3. Three-level diode clamped bidirectional PFC converter

Figure 4 shows five-level flying capacitor bidirectional PFC converter topology. (Kamaga et al., 2011) specifies that harmonics decrease if the number of converters levels increase, however, it will not be practical because of the large number of capacitors. The performances of five-level flying capacitor and five-level diode clamped topologies are compared in (He et al., 2016). Diode-clamped topology is preferable in terms of cost and performance.

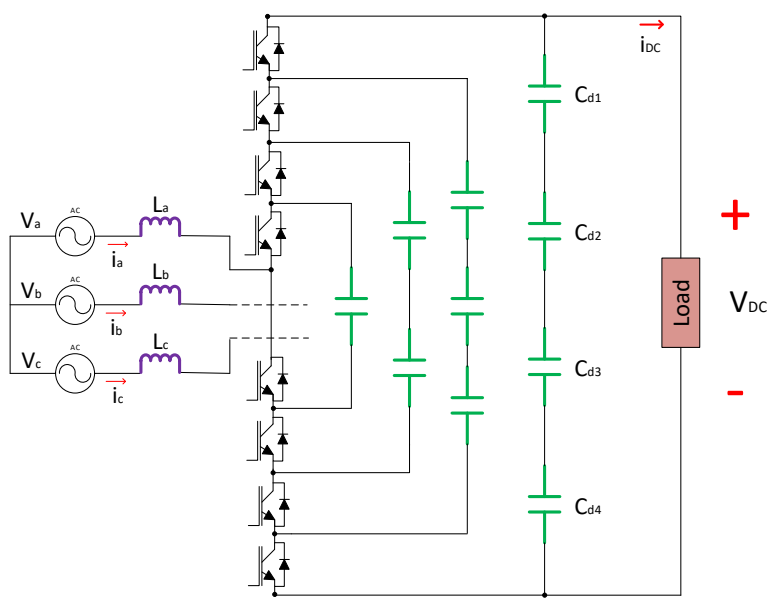

Figure 4. Five level flying capacitor bidirectional PFC converter

Figure 5 shows five-level diode-clamped bidirectional PFC converter topology. As the number of converter levels increase, the phase-to-phase THD decreases in diode-clamped converters. However, since the component number increase, the cost of the system increases (Prajapati et al., 2014).

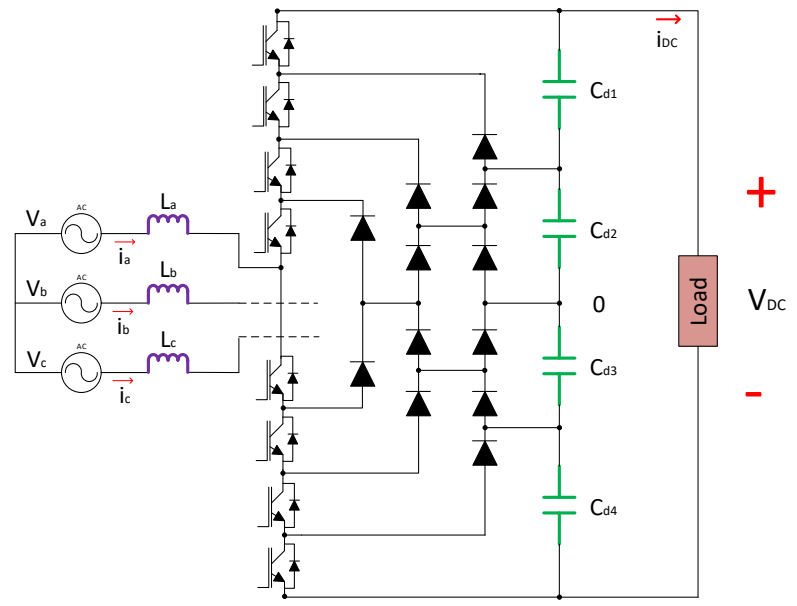

Figure 5. Five-level diode-clamped bidirectional PFC converter
The cascade H-bridge converter provides multilevel voltage with the separate power supplies that operates each H-bridge converter, shown in Figure 6. Five-level diode-clamped and fivelevel flying capacitors multilevel converters are compared with cascade module converter. Among the three topologies, the cascade module gives the minimum harmonics in the output voltage (Prayag et al., 2017). However, the need for many DC choppers is not practical in application (Shaikh et al., 2021).

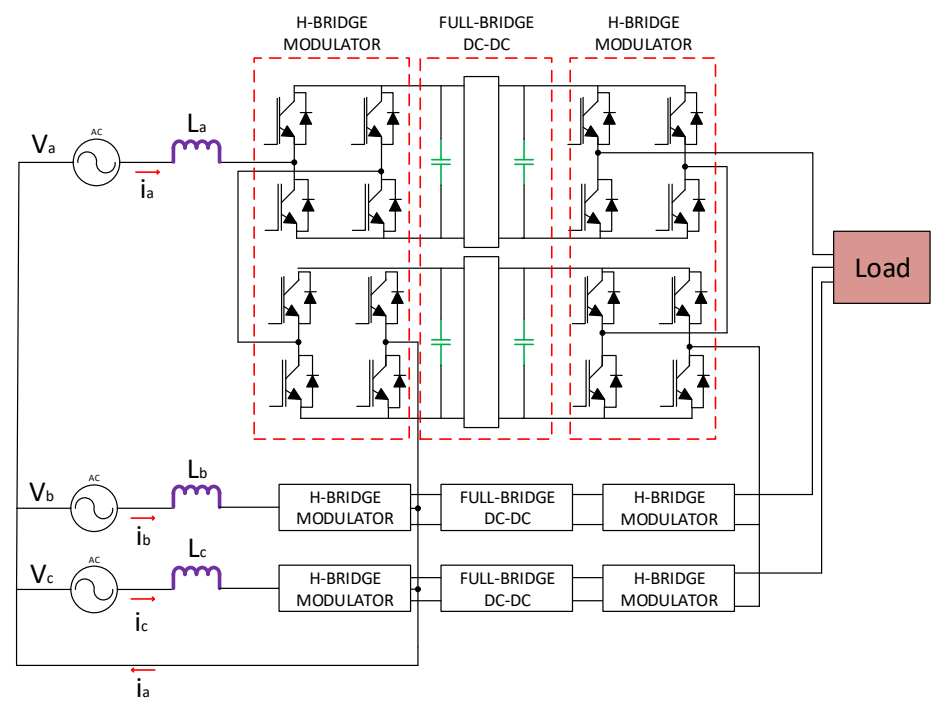

Figure 6. There-level converter using PFC cascade modules

Capacitor charge and discharge can be balanced when using a multilevel bidirectional converter for reactive power compensation without voltage imbalance problem (Singh et al., 2004). Diode-clamped multilevel converters control is easier in terms of reactive power flow. However, they require more clamping diodes. The disadvantage of multilevel converters with flying capacitors is that many capacitors are required because of the number of levels; this makes the system less reliable and more bulky. The biggest disadvantage of cascade multilevel converters is that they need separate DC sources. Therefore, it limits the user in terms of application (Bhat et al., 2008; Cui et al., 2018).

\section{Control Strategies}

Control strategies are developed to improve EV charging system performance and system quality (Saleeb et al., 2019). The described topologies emphasize the balance of the neutral point potential. There are many control techniques in the literature for their control. The conversion part and the soft switching part are controlled in AC-DC PFC converters.

Control strategy is very important for high PF. All modulation techniques such as SPWM, SVPWM developed for inverters can also be used in these rectifiers. Controlling the DC link voltage of bidirectional AC-DC PFC converters require a feedback control loop. The DC output voltage is the system output. It is used as feedback in various control techniques such as PI controller, PID controller and sliding mode control.

While the converters are controlled, the error signal is found by comparing the DC output voltage in the rectifier with a reference voltage. This error is used to generate a sample sinusoidal waveform with the same frequency as the grid. This sample waveform is used to create the PWM to control the switches in rectifier. Switching signals are controlled as a voltage 
source current controlled or a voltage controlled PWM rectifier. While current controller is used for input current, the voltage controller is used for magnitude and phase of the voltage (Sayed et al., 2016).

There are many control techniques for controlling multilevel converters (Yacoubi et al., 2005). Space vector pulse width modulation (SVPWM) techniques in particular perform well for control of these converters. Therefore, SVPWM control techniques are developed (Menon et al., 2021; Sreedhar et al., 2021; Vivek et al., 2021). General control block diagram for ACDC PFC converters is shown in Figure 7.

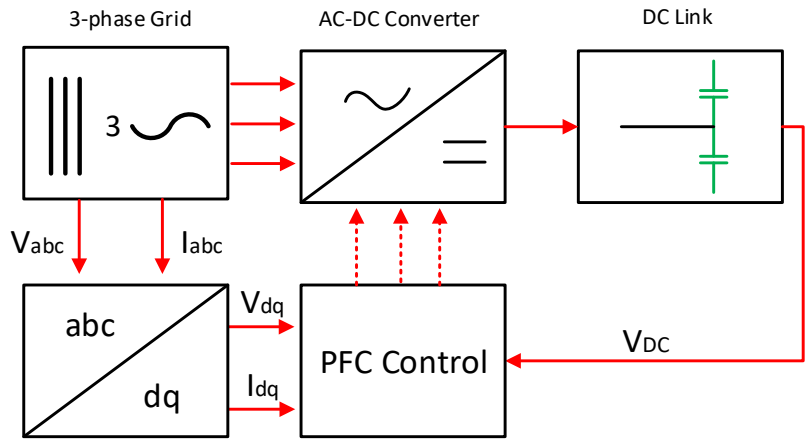

Figure 7. General control block diagram for AC-DC PFC converters

$D q$ transform is applied to the sensed voltage and current signals to simplify the control analysis in three-phase converters. The converted voltage or current is used in closed loop controllers to derive reference voltage or current signals.

\section{Selection Criteria of Three-Phase AC-DC PFC Converters for EV Fast Charging}

Three-phase bidirectional multilevel AC-DC PFC converters are preferred for new technology high voltage and high power applications. The following factors are considered in the selection of these converters, which are also considered for fast charging (Kavianipour et al., 2021).

- input power quality (THD and PF),

- The fluctuation of the DC voltage output,

- Unidirectional and bidirectional power flow,

- DC power requirement at the output

- Cost, size and weight;

- Efficiency;

- Noise level (EMI, RFI, etc.),

- Reliability;

- Environment (ambient temperature, pollution, humidity)

In summary, we can say that DC output regulation, high input power factor and low THD are important for EV chargers.

\section{Conclusion and Future Development}

In this paper, detailed information is given about the threephase bidirectional multilevel AC-DC PFC topologies for EV fast charging. The mentioned PFCs are used in high power applications. Today, the aim is to reduce switching losses at high switching frequency in these topologies, to reduce the size of the elements, and to reduce the use of bulky filters. Therefore, control algorithms and soft switching techniques are developed. Multilevel converters are popular as they offer less stress and low THD in devices. In addition, solid state device technology developed for switching elements has made these converters attractive. New developments in control algorithms will provide support for three-phase PFC converters in the near future. This paper can be a good reference for selection of the right topology for EV charging infrastructure.

\section{References}

Akter, P., Mekhilef, S., Tan, N. M. L., \& Akagi, H. (2015). Model predictive control of bidirectional AC-DC converter for energy storage system. Journal of Electrical Engineering and Technology, 10(1), 165-175. doi: 10.5370/JEET.2015.10.1.165

Alves, W. C., Morais, L. M. F., \& Cortizo, P. C. (2018). Design of an highly efficient AC-DC-AC three-phase converter using sic for ups applications. Electronics (Switzerland), 7(12), 425. doi: 10.3390/electronics 7120425

Balasubramanian, R., \& Palani, S. (2016). Simulation and Performance Evaluation of Shunt Hybrid Power Filter for Power Quality Improvement Using PQ Theory. International Journal of Electrical and Computer Engineering (IJECE), 6(6), 2603-2609. doi: 10.11591/ijece.v6i6.12011

Bhat, A. H., \& Agarwal, P. (2008). Three-phase, power quality improvement AC/DCconverters. Electric Power Systems Research, 78(2), 276-289. doi: 10.1016/j.epsr.2007.02.002

Channegowda, J., Pathipati, V. K., \& Williamson, S. S. (2015). Comprehensive review and comparison of DC fast charging converter topologies: Improving electric vehicle plug-towheels efficiency. IEEE International Symposium on Industrial Electronics, 2015-September, 263-268. doi: 10.1109/ISIE.2015.7281479

Chen, H., \& Zhao, H. (2016). Review on pulse-width modulation strategies for common-mode voltage reduction in threephase voltage-source inverters. IET Power Electronics, 9(14), 2611-2620. doi: 10.1049/iet-pel.2015.1019

Chlebis, P., Tvrdon, M., Havel, A., \& Baresova, K. (2014). Comparison of Standard and Fast Charging Methods for Electric Vehicles. Advances in Electrical and Electronic Engineering, 12(2), 111-116. doi: 10.15598/AEEE.V12I2.975

Cui, D., \& Ge, Q. (2018). A Novel Hybrid Voltage Balance Method for Five-Level Diode-Clamped Converters. IEEE Transactions on Industrial Electronics, 65(8), 6020-6031. doi: 10.1109/TIE.2017.2784399

Electromagnetic compatibility (EMC)-Part 3-2: Limits-Limits for harmonic current emissions (equipment input current $\leq 16$ A per phase). (2014).

Elrajoubi, A. M., Ang, S. S., \& George, K. (2019). Design and analysis of a new GaN-based AC/DC converter for battery charging application. IEEE Transactions on Industry Applications, 55(4), 4044-4052. doi: 10.1109/TIA.2019.2915687

Garg, P., Essakiappan, S., Krishnamoorthy, H. S., \& Enjeti, P. N. (2015). A fault-tolerant three-phase adjustable speed drive topology with active common-mode voltage suppression. IEEE Transactions on Power Electronics, 30(5), 28282839. doi: 10.1109/TPEL.2014.2361905 
Habib, S., Khan, M. M., Abbas, F., \& Tang, H. (2018). Assessment of electric vehicles concerning impacts, charging infrastructure with unidirectional and bidirectional chargers, and power flow comparisons. In International Journal of Energy Research (Vol. 42, Issue 11, pp. 34163441). John Wiley and Sons Ltd. doi: 10.1002/er.4033

He, L., \& Cheng, C. (2016). A Flying-Capacitor-Clamped FiveLevel Inverter Based on Bridge Modular SwitchedCapacitor Topology. IEEE Transactions on Industrial Electronics, 63(12), 7814-7822. doi: 10.1109/TIE.2016.2607155

IEEE 597-1983 - IEEE Standard Practices and Requirements for General Purpose Thyristor DC Drives. (n.d.). In IEEE. Retrieved from https://standards.ieee.org/standard/5971983.html

IEEE Guide for Specification of High-Voltage Direct -Current Systems Part I - Steady-State Performance. (1987). Retrieved from https://ieeexplore.ieee.org/stamp/stamp.jsp?arnumber $=264$ 85

Justus Rabi, B., \& V, B. K. (2015). A Novel Power Factor Correction Rectifier for Enhancing Power Quality. International Journal of Power Electronics and Drive System (IJPEDS), 6(4), 772-780.

K. T. Chau. (2016). Energy Systems for Electric and Hybrid Vehicles. In K. T. Chau (Ed.), Energy Systems for Electric and Hybrid Vehicles. Institution of Engineering and Technology. doi: 10.1049/PBTR002E

Kamaga, M., Sung, K., Sato, Y., \& Ohashi, H. (2011). An investigation of flying capacitor converter for circuit integration. IEEJ Transactions on Electrical and Electronic Engineering, 6(4), 376-383. doi: 10.1002/tee.20671

Kavianipour, M., Fakhrmoosavi, F., Singh, H., Ghamami, M., Zockaie, A., Ouyang, Y., \& Jackson, R. (2021). Electric vehicle fast charging infrastructure planning in urban networks considering daily travel and charging behavior. Transportation Research Part D: Transport and Environment, 93, 102769. doi: 10.1016/j.trd.2021.102769

Khaligh, A., \& Dusmez, S. (2012). Comprehensive topological analysis of conductive and inductive charging solutions for plug-in electric vehicles. IEEE Transactions on Vehicular Technology, 61(8), 3475-3489. doi: 10.1109/TVT.2012.2213104

Kushwaha, R., \& Singh, B. (2020a). Design and Development of Modified BL Luo Converter for PQ Improvement in EV Charger. IEEE Transactions on Industry Applications, 56(4), 3976-3984. doi: 10.1109/TIA.2020.2988197

Kushwaha, R., \& Singh, B. (2020b). Interleaved Landsman Converter Fed EV Battery Charger with Power Factor Correction. IEEE Transactions on Industry Applications, 56(4), 4179-4192. doi: 10.1109/TIA.2020.2988174

Lee, J. H., Moon, J. S., Lee, Y. S., Kim, Y. R., \& Won, C. Y. (2011). Fast charging technique for EV battery charger using threephase AC-DC boost converter. IECON Proceedings (Industrial Electronics Conference), 4577-4582. doi: 10.1109/IECON.2011.6120064

Lee, J. Y., Heo, K. W., Kim, K. T., \& Jung, J. H. (2020). Analysis and design of three-phase buck rectifier employing UPS to supply high reliable dc power. Energies, 13(7), 1704. doi: 10.3390/en13071704

Liu, J., Xu, W., Chan, K. W., Liu, M., Zhang, X., \& Chan, N. H. L. (2020). A Three-Phase Single-Stage AC-DC WirelessPower-Transfer Converter with Power Factor Correction and Bus Voltage Control. IEEE Journal of Emerging and Selected Topics in Power Electronics, 8(2), 1782-1800. doi: 10.1109/JESTPE.2019.2916258

Menon, M., \& Jacob, B. (2021). A Simplified Space Vector Pulse Density Modulation Scheme without Coordinate Transformation and Sector Identification. IEEE Transactions on Industrial Electronics, 1-1. doi: 10.1109/TIE.2021.3080201

Metwly, M. Y., Abdel-Majeed, M. S., Abdel-Khalik, A. S., Hamdy, R. A., Hamad, M. S., \& Ahmed, S. (2020). A Review of Integrated On-Board EV Battery Chargers: Advanced Topologies, Recent Developments and Optimal Selection of FSCW Slot/Pole Combination. IEEE Access, 8 , 85216-85242. doi: 10.1109/ACCESS.2020.2992741

Monteiro, V., Afonso, J., Sousa, T., \& Afonso, J. L. (2020). The role of off-board EV battery chargers in smart homes and smart grids: Operation with renewables and energy storage systems. Electric Vehicles in Energy Systems: Modelling, Integration, Analysis, and Optimization, 47-72. doi: 10.1007/978-3-030-34448-1_3

Monteiro, V., Ferreira, J. C., Nogueiras Melendez, A. A., Couto, C., \& Afonso, J. L. (2018). Experimental Validation of a Novel Architecture Based on a Dual-Stage Converter for Off-Board Fast Battery Chargers of Electric Vehicles. IEEE Transactions on Vehicular Technology, 67(2), 1000-1011. doi: 10.1109/TVT.2017.2755545

Nayak, S. K. (2019, December 1). Electric Vehicle Charging Topologies, Control Schemes for Smart City Application. 2019 IEEE Transportation Electrification Conference, ITEC-India 2019. doi: 10.1109/ITECIndia48457.2019.ITECIndia2019-229

Prajapati, D., Ravindran, V., Sutaria, J., Patel, P., \& Professor, A. (2014). A Comparative Study of Three Phase 2-Level VSI with 3-Level and 5-Level Diode Clamped Multilevel Inverter. International Journal of Emerging Technology and Advanced Engineering , 4(4), 713. Retrieved from www.ijetae.com

Praneeth, A. V. J. S., \& Williamson, S. S. (2018). A Review of Front End AC-DC Topologies in Universal Battery Charger for Electric Transportation. 2018 IEEE Transportation and Electrification Conference and Expo, ITEC 2018, 916-921. doi: 10.1109/ITEC.2018.8450186

Prayag, A., \& Bodkhe, S. (2017, February 13). A comparative analysis of classical three phase multilevel (five level) inverter topologies. 1st IEEE International Conference on Power Electronics, Intelligent Control and Energy Systems, ICPEICES 2016. doi: 10.1109/ICPEICES.2016.7853567

Sah, S., \& Rizvi, T. (2021). Power Quality Improvement using Shunt Active Filters with Multilevel Inverter. International Journal for Research Trends and Innovation , 6(4). Retrieved from www.ijrti.org

Saleeb, H., Sayed, K., Kassem, A., \& Mostafa, R. (2019). Power management strategy for battery electric vehicles. IET Electrical Systems in Transportation, 9(2), 65-74. doi: 10.1049/iet-est.2018.5026

Sam, C. A., \& Jegathesan, V. (2021). Bidirectional integrated onboard chargers for electric vehicles - a review. Sadhana Academy Proceedings in Engineering Sciences, 46(1), 114. doi: 10.1007/s12046-020-01556-2

Sandoval, J. J., Essakiappan, S., \& Enjeti, P. (2015). A bidirectional series resonant matrix converter topology for electric vehicle DC fast charging. Conference Proceedings - IEEE Applied Power Electronics Conference and 
Exposition - APEC, 2015-May(May), 3109-3116. doi: 10.1109/APEC.2015.7104795

Sayed, K., \& Gabbar, H. (2016). Electric Vehicle to Power Grid Integration Using Three-Phase Three-Level AC/DC Converter and PI-Fuzzy Controller. Energies, 9(7), 532. doi: 10.3390/en9070532

Shaikh, O., Siddiqui, S. ul I., Khan, A., Riaz, S., \& Tarique, S. (2021). Three Phase Transformer Based Cascaded HBridge Multilevel Inverter. 2021 International Conference on Emerging Power Technologies (ICEPT), 1-5. doi: 10.1109/ICEPT51706.2021.9435531

Sharma, G., Sood, V. K., Alam, M. S., \& Shariff, S. M. (2020). Comparison of common DC and AC bus architectures for EV fast charging stations and impact on power quality. ETransportation, 5, $100066 . \quad$ doi: 10.1016/j.etran.2020.100066

Singh, B., Singh, B. N., Chandra, A., Al-Haddad, K., Pandey, A., $\&$ Kothari, D. P. (2004). A review of three-phase improved power quality AC-DC converters. IEEE Transactions on Industrial Electronics, 51(3), 641-660. doi: 10.1109/TIE.2004.825341

Singh, B., Singh, S., Chandra, A., \& Al-Haddad, K. (2011). Comprehensive study of single-phase AC-DC power factor corrected converters with high-frequency isolation. IEEE Transactions on Industrial Informatics, 7(4), 540-556. doi: 10.1109/TII.2011.2166798

Soeiro, T., Friedli, T., \& Kolar, J. W. (2012). Three-phase high power factor mains interface concepts for electric vehicle battery charging systems. Conference Proceedings - IEEE Applied Power Electronics Conference and Exposition APEC, 2603-2610. doi: 10.1109/APEC.2012.6166190

Sreedhar, R., Karunanithi, K., Chandrasekar, P., \& Teja, R. B. (2021). Nearest Space-Vector Control Strategy for HighResolution Multilevel Inverters. 6th International Conference for Convergence in Technology (I2CT), 1-6. doi: 10.1109/i2ct51068.2021.9417882

Tan, K. M., Ramachandaramurthy, V. K., \& Yong, J. Y. (2016). Three-phase bidirectional electric vehicle charger for vehicle to grid operation and grid voltage regulation. 2016 IEEE Transportation Electrification Conference and Expo, Asia-Pacific, ITEC Asia-Pacific 2016, 7-12. doi: 10.1109/ITEC-AP.2016.7512913

Turksoy, O., Yilmaz, U., \& Teke, A. (2018). Overview of Battery Charger Topologies in Plug-In Electric and Hybrid Electric Vehicles. 16th International Conference on Clean Energy (ICCE-2018), 1-8. Retrieved from https://www.researchgate.net/publication/327422059

Verma, A., \& Singh, B. (2019). Multi-Objective Reconfigurable Three-Phase Off-Board Charger for EV. IEEE Transactions on Industry Applications, 55(4), 4192-4203. doi: 10.1109/TIA.2019.2908950

Vivek, G., Nair, M. D., Biswas, J., \& Barai, M. (2021). Design space exploration of optimized hybrid SVPWM techniques based on spatial region for three level VSI. Electrical Engineering, 1, 3. doi: 10.1007/s00202-021-01245-1

Wang, Q., Deng, F., Liu, C., Heng, Q., \& Chen, Z. (2019). Thyristor-based modular multilevel converter-HVDC systems with current interruption capability. IET Power Electronics, 12(12), 3056-3067. doi: 10.1049/ietpel.2019.0213

Yacoubi, L., Al-Haddad, K., Fnaiech, F., \& Dessaint, L. A. (2005). A DSP-based implementation of a new nonlinear control for a three-phase neutral point clamped boost rectifier prototype. IEEE Transactions on Industrial Electronics, 52(1), 197-205. doi: 10.1109/TIE.2004.837913

Yaramasu, V., Dekka, A., \& Kouro, S. (2021). Multilevel converters for renewable energy systems. In Multilevel Inverters (pp. 155-184). Elsevier. doi: 10.1016/b978-0323-90217-5.00007-1

Yildirim, D., Ozturk, S., Cadirci, I., \& Ermiş, M. (2020). All SiC PWM rectifier-based off-board ultrafast charger for heavy electric vehicles. IET Power Electronics, 13(3), 483-494. doi: 10.1049/iet-pel.2019.0583

Yilmaz, M., \& Krein, P. T. (2013). Review of battery charger topologies, charging power levels, and infrastructure for plug-in electric and hybrid vehicles. In IEEE Transactions on Power Electronics (Vol. 28, Issue 5, pp. 2151-2169). doi: 10.1109/TPEL.2012.2212917

Yuan, J., Dorn-Gomba, L., Callegaro, A. D., Reimers, J., \& Emadi, A. (2021). A review of bidirectional on-board chargers for electric vehicles. In IEEE Access (Vol. 9, pp. 51501-51518). Institute of Electrical and Electronics Engineers Inc. doi: 10.1109/ACCESS.2021.3069448

Zhang, Z., Xu, H., Shi, L., Li, D., \& Han, Y. (2012). A unit power factor DC fast charger for electric vehicle charging station. Conference Proceedings - 2012 IEEE 7th International Power Electronics and Motion Control Conference - ECCE Asia, IPEMC 2012, 1, 411-415. doi: 10.1109/IPEMC.2012.6258896 